\title{
Application methods of Azospirillum brasilense in first- and second-crop corn
}

\author{
Rita de C. F. Alvarez ${ }^{1}$, Jamile Benetão ${ }^{1}$, Gustavo R. Barzotto ${ }^{2}$, Maria G. de O. Andrade ${ }^{3}$ \& \\ Sebastião F. de Lima ${ }^{1}$
}

\begin{abstract}
${ }^{1}$ Universidade Federal do Mato Grosso do Sul/Departamento de Agronomia. Chapadão do Sul, MS, Brasil. E-mail: ritacfalvarez@gmail.com (Corresponding author) - ORCID: 0000-0002-1655-9939; jamile.benetao@gmail.com - ORCID: 0000-0002-0838-4083; sebastiao.lima@ufms.br - ORCID: 0000-00015693-912X

${ }^{2}$ Universidade Estadual Paulista "Júlio de Mesquita Filho"/Faculdade de Ciências Agronômicas/Departamento de Horticultura. Botucatu, SP, Brasil. E-mail: grbarzotto@gmail.com - ORCID: 0000-0002-7307-0208

${ }^{3}$ Universidade Estadual Paulista "Júlio de Mesquita Filho"/Faculdade de Engenharia/Sistemas de Produção. Ilha Solteira, SP, Brasil. E-mail: gabriela13andrade@hotmail.com - ORCID: 0000-0002-3348-5150
\end{abstract}

\begin{abstract}
This study investigated whether inoculation of Azospirillum brasilense in the seeds or sowing furrow could reduce the need for nitrogen fertilizer application in the corn grown in the first and second crop harvest. The experiments were conducted, in the municipality of Chapadão do Sul, MS, Brazil, in the first crop harvest (2014/2015) and in the second crop harvest (2016). The early maturity hybrids CD $384 \mathrm{HX}$ and P3132H were used in the first and in the second harvest corn, respectively. In both experiments, the experimental design was the randomized blocks with eight treatments and three repetitions. At the silking (R1 stage), the leaf $\mathrm{N}$ concentration, relative chlorophyll index and nitrate reductase activity were measured, at the physiological maturity (R6 stage), the plant height, first ear insertion height, one hundred grain mass, grain yield and grain $\mathrm{N}$ concentration were measured. In the first crop harvest, the application of Azospirillum brasilense at the sowing furrow resulted in higher $\mathrm{N}$ concentration and relative chlorophyll index in corn leaves, while the inoculation of $A$. brasilense in the seeds provided higher $\mathrm{N}$ concentration in the grains. The nitrate reductase activity in corn leaves was lower when inoculation was performed. In the second crop harvest, the inoculation did not affected the $\mathrm{N}$ concentration in the leaves and in the grains, the relative chlorophyll index and the growth of corn plants. Inoculation in the sowing furrow associated with the application of $20 \mathrm{~kg} \mathrm{~N} \mathrm{ha}^{-1}$ at sowing and $120 \mathrm{~kg} \mathrm{~N} \mathrm{ha}^{-1}$ at topdressing resulted in lower nitrate reductase activity.
\end{abstract}

Key words: Zea mays, diazotrophic bacteria, nitrogen concentration, nitrate reductase activity

\section{Formas de aplicação de Azospirillum brasilense no milho primeira e segunda safra}

\begin{abstract}
RESUMO: Objetivou-se verificar se a inoculação de Azospirillum brasilense via semente ou sulco de semeadura pode reduzir a necessidade de adubação nitrogenada no milho, em primeira e segunda safra. Os experimentos foram conduzidos, no município de Chapadão do Sul, MS, em primeira safra (2014/2015) e segunda safra (2016). Na primeira safra utilizou-se o híbrido CD $384 \mathrm{HX}$ e na segunda safra, o híbrido triplo $\mathrm{P} 3132 \mathrm{H}$, ambos de ciclo precoce. Para os dois experimentos, o delineamento experimental foi em blocos ao acaso com oito tratamentos e três repetições. Foram mensurados, no estádio R1: o teor de $\mathrm{N}$ foliar, índice relativo de clorofila, atividade da redutase de nitrato, e na maturação fisiológica: a altura de plantas e de inserção de primeira espiga, massa de cem grãos, produtividade de grãos e teor de N nos grãos. Na primeira safra, a inoculação de Azospirillum brasilense na cultura do milho proporcionou maior teor de $\mathrm{N}$ e índice relativo de clorofila quando feita no sulco de semeadura, enquanto a inoculação nas sementes proporcionou maior teor de $\mathrm{N}$ nos grãos. A atividade da enzima nitrato redutase nas folhas foi menor quando realizada a inoculação. Na segunda safra a inoculação não afetou os teores de $\mathrm{N}$ foliar e de grãos, o índice relativo de clorofila, afetou o crescimento das plantas. A inoculação no sulco de semeadura aliada à aplicação de $20 \mathrm{~kg} \mathrm{de} \mathrm{N} \mathrm{ha}^{-1}$ na semeadura $+120 \mathrm{~kg} \mathrm{de} \mathrm{N} \mathrm{ha}^{-1} \mathrm{em}$ cobertura resultou em menor atividade da enzima nitrato redutase.
\end{abstract}

Palavras-chave: Zea mays, bactéria diazotróficas, teor de nitrogênio, atividade do nitrato redutase 


\section{INTRODUCTION}

High grain yield levels of cereal crops, such as corn, can be achieved when large amounts of fertilizers are applied, especially nitrogen fertilizer. Nitrogen is one of the nutrients most required by corn crop and is related to the leaf area index, biomass accumulation and grain yield (França et al., 2011). However, optimization of the nitrogen use efficiency is fundamental to obtain high crop grain yield, reduce the production cost and reduce the environmental and economic damages related to the inadequate use or low efficiency of the fertilization. In this sense, the association of cereal crops with endophytic diazotrophic bacteria may represent one of the most promising alternatives to promote plant growth, soil management and environmental quality.

Regardless of soil $\mathrm{N}$ availability, the absorption efficiency is the most important component of the $\mathrm{N}$ use efficiency (Vale et al., 2012), creating the possibility of using the bacterium Azospirillum brasilense. Martins et al. (2017) used corn seeds inoculated with $A$. brasilense and reported a higher $\mathrm{N}$ recovery provided by mineral fertilization, which increased the grain yield of the crop. Ferreira et al. (1987) and Pereira-Defilippi et al. (2017) verified changes in the nitrate reductase (NR) activity, an enzyme directly related to the $\mathrm{N}$ metabolism of the plant.

However, the response to inoculation of $A$. brasilense can vary with the plant genotype (Brusamarello-Santos et al., 2017), edaphoclimatic conditions (Martins et al., 2017), inoculation method and $\mathrm{N}$ availability in the growing medium (PereiraDefilippi et al., 2017). Thus, the objective of this study was to investigate whether inoculation of $A$. brasilense in the seeds or sowing furrow can reduce the need for $\mathrm{N}$ fertilizer application in the corn grown in the first and second crop harvest.

\section{Material ANd Methods}

The experiments were carried out during the 2014/2015 growing season ( $1^{\text {st }}$ harvest corn $)$ and 2016 growing season $\left(2^{\text {nd }}\right.$ harvest corn), in a deep Oxisol at the Universidade Federal do Mato Grosso do Sul, Campus of Chapadão do Sul, MS, Brazil. The regional climate, according to the Köppen classification is Aw, characterized as tropical climate with a mean annual temperature of $22.7^{\circ} \mathrm{C}$, and mean annual rainfall of $1,598 \mathrm{~mm}$. The daily rainfall and temperature data gathered during the period of the experiments are shown in Figure 1.

Before starting the experiments, the soil was sampled from the $0-0.20 \mathrm{~m}$ layer for the chemical characterization. The main chemical properties were as follow: $\mathrm{pH}$ in $\mathrm{CaCl}_{2}$ of 4.7 , $29.5 \mathrm{~g} \mathrm{dm}^{-3}$ of organic matter, $11.6 \mathrm{mg} \mathrm{dm}^{-3}$ of $\mathrm{P}$ (Resin), $5.3 \mathrm{cmol}_{c} \mathrm{dm}^{-3}$ of $\mathrm{H}+\mathrm{Al}, 0.26 \mathrm{cmol}_{c} \mathrm{dm}^{-3}$ of K, $2.3 \mathrm{cmol}_{c} \mathrm{dm}^{-3}$ of $\mathrm{Ca}^{2+}, 0.5 \mathrm{cmol}_{\mathrm{c}} \mathrm{dm}^{-3}$ of $\mathrm{Mg}^{2+}, 8.4 \mathrm{cmol}_{\mathrm{c}} \mathrm{dm}^{-3}$ of cation exchange capacity and $37 \%$ of soil base saturation.

The experiments were arranged in a complete randomized block design with eight treatments (Table 1) and three repetitions. The experimental units consisted of five $5.0-\mathrm{m}$ long rows, with $0.45 \mathrm{~m}$ between rows. The observation area comprised the three central rows of each plot, disregarding $0.50 \mathrm{~m}$ of each edge, totaling $5.4 \mathrm{~m}^{2}$.

The triple hybrid CD $384 \mathrm{HX}$ was sown in the first corn crop (2014/2015 season), while in the second crop (2016

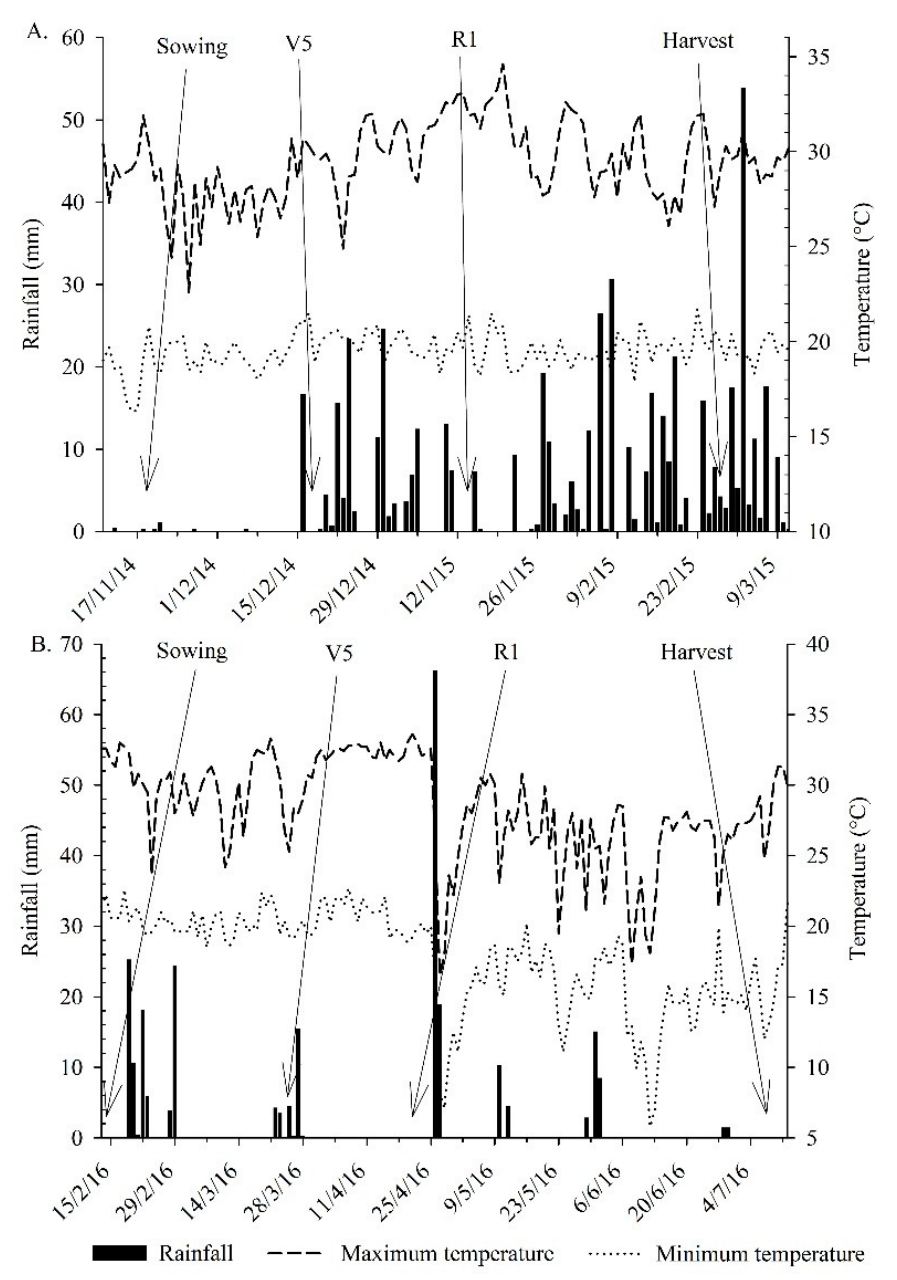

V5 stage - Topdressing nitrogen fertilization; R1 stage - Leaf sampling to determine the $\mathrm{N}$ concentration

Figure 1. Daily rainfall and maximum and minimum temperature during the conduction period of the experiments with corn crop in the $1^{\text {st }}$ crop harvest $(2014 / 2015)$ and in the $2^{\text {nd }}$ crop harvest (2016), in Chapadão do Sul, MS, Brazil

season) the triple hybrid $\mathrm{P} 3132 \mathrm{H}$ was sown. Both hybrids are of early maturity, and the recommended plant population is 60,000 plants ha $^{-1}$.

In their respective treatments, the seeds were previously inoculated with the Azospirillum brasilense $\mathrm{AbV}_{5}$ and $\mathrm{AbV}_{6}$ strains $\left(2 \times 10^{8}\right.$ viable cells $\left.\mathrm{mL}^{-1}\right)$, applying $100 \mathrm{~mL} 20 \mathrm{~kg}^{-1}$ of seeds. The seeds were placed in a plastic bag, and after addition of the inoculant, they were homogenized for $2 \mathrm{~min}$ to standardize the inoculant on all seeds. The application of the inoculant to the sowing furrow was performed using $500 \mathrm{~mL} \mathrm{ha}^{-1}$ of the commercial product, which was sprayed directly on the seeds, and then the furrow was closed, and the seeds covered with soil.

In both experiments, sowing fertilization was performed with the application of $412 \mathrm{~kg} \mathrm{ha}^{-1}$ of the fertilizer 0-20-20+ $11 \%$ of $\mathrm{Ca}+4 \%$ of $\mathrm{S}$, according to the results of the soil analysis and the fertilization recommendation for corn crop (Sousa \& Lobato, 2004). Application of $\mathrm{N}$ fertilizer in topdressing was performed when the plants had the fifth leaf fully emerged (V5 stage). The $\mathrm{N}$ doses were applied according to the treatments, in the row of corn planting, without incorporation to the soil. The $\mathrm{N}$ fertilizer used was urea ( $45 \%$ of $\mathrm{N})$. At the time of $\mathrm{N}$ 
Table 1. Treatments used and their description

\begin{tabular}{|c|c|}
\hline Treatments & Description (1 $1^{\text {st }}$ crop harvest) \\
\hline US + N1 & Uninoculated seeds $+10 \mathrm{~kg} \mathrm{ha}^{-1}$ of $\mathrm{N}$ at sowing $+60 \mathrm{~kg} \mathrm{ha}^{-1}$ of $\mathrm{N}$ at topdressing \\
\hline US + N2 & Uninoculated seeds $+20 \mathrm{~kg} \mathrm{ha}^{-1}$ of $\mathrm{N}$ at sowing $+120 \mathrm{~kg} \mathrm{ha}^{-1}$ of $\mathrm{N}$ at topdressing \\
\hline IS + NO & Inoculant applied at seeds, not fertilized with nitrogen \\
\hline IS + N1 & Inoculant applied at seeds $+10 \mathrm{~kg} \mathrm{ha}^{-1}$ of $\mathrm{N}$ at sowing $+60 \mathrm{~kg} \mathrm{ha}^{-1}$ of $\mathrm{N}$ at topdressing \\
\hline IS + N2 & Inoculant applied at seeds $+20 \mathrm{~kg} \mathrm{ha}^{-1}$ of $\mathrm{N}$ at sowing $+120 \mathrm{~kg} \mathrm{ha}^{-1}$ of $\mathrm{N}$ at topdressing \\
\hline $\mathrm{IF}+\mathrm{N} 0$ & $500 \mathrm{~mL} \mathrm{ha}^{-1}$ of inoculant applied at sowing furrow, not fertilized with nitrogen \\
\hline $\mathrm{IF}+\mathrm{N1}$ & $500 \mathrm{~mL}^{-1}$ of inoculant applied at sowing furrow $+10 \mathrm{~kg} \mathrm{ha}^{-1}$ of $\mathrm{N}$ at sowing $+60 \mathrm{~kg} \mathrm{ha}^{-1}$ of $\mathrm{N}$ at topdressing \\
\hline \multirow{2}{*}{$\mathrm{IF}+\mathrm{N} 2$} & $500 \mathrm{~mL} \mathrm{ha}^{-1}$ of inoculant applied at sowing furrow $+20 \mathrm{~kg} \mathrm{ha}^{-1}$ of $\mathrm{N}$ at sowing $+120 \mathrm{~kg} \mathrm{ha}^{-1}$ of $\mathrm{N}$ at topdressing \\
\hline & Description (2 ${ }^{\text {nd }}$ crop harvest) \\
\hline $\mathrm{US}+\mathrm{N} 1$ & Uninoculated seeds $+10 \mathrm{~kg} \mathrm{ha}^{-1}$ of $\mathrm{N}$ at sowing $+50 \mathrm{~kg} \mathrm{ha}^{-1}$ of $\mathrm{N}$ at topdressing \\
\hline $\mathrm{US}+\mathrm{N} 2$ & Uninoculated seeds $+20 \mathrm{~kg} \mathrm{ha}^{-1}$ of $\mathrm{N}$ at sowing $+100 \mathrm{~kg} \mathrm{ha}^{-1}$ of $\mathrm{N}$ at topdressing \\
\hline IS + NO & Inoculant applied at seeds, not fertilized with nitrogen \\
\hline $\mathrm{IS}+\mathrm{N} 1$ & Inoculant applied at seeds $+10 \mathrm{~kg} \mathrm{ha}^{-1}$ of $\mathrm{N}$ at sowing $+50 \mathrm{~kg} \mathrm{ha}^{-1}$ of $\mathrm{N}$ at topdressing \\
\hline $\mathrm{IS}+\mathrm{N} 2$ & Inoculant applied at seeds $+20 \mathrm{~kg} \mathrm{ha}^{-1}$ of $\mathrm{N}$ at sowing $+100 \mathrm{~kg} \mathrm{ha}^{-1}$ of $\mathrm{N}$ at topdressing \\
\hline $\mathrm{IF}+\mathrm{N} 0$ & $500 \mathrm{~mL} \mathrm{ha}^{-1}$ of inoculant applied at sowing furrow, not fertilized with nitrogen \\
\hline $\mathrm{IF}+\mathrm{N} 1$ & $500 \mathrm{~mL} \mathrm{ha}^{-1}$ of inoculant applied at sowing furrow $+10 \mathrm{~kg} \mathrm{ha}^{-1}$ of $\mathrm{N}$ at sowing $+50 \mathrm{~kg} \mathrm{ha}^{-1}$ of $\mathrm{N}$ at topdressing \\
\hline $\mathrm{IF}+\mathrm{N} 2$ & $500 \mathrm{~mL} \mathrm{ha}^{-1}$ of inoculant applied at sowing furrow $+20 \mathrm{~kg} \mathrm{ha}^{-1}$ of $\mathrm{N}$ at sowing $+100 \mathrm{~kg} \mathrm{ha}^{-1}$ of $\mathrm{N}$ at topdressing \\
\hline
\end{tabular}

application, the soil had optimum moisture conditions to provide adequate dissolution of the fertilizer and minimize the losses of $\mathrm{N}$ by ammonia volatilization.

In the first crop harvest, weed management was carried out with the post-emergence herbicide tembotrione $\left(108.8+1000 \mathrm{~g} \mathrm{ha}^{-1}\right.$ of the active ingredient). The application was performed in the V4 stage. Pest and disease control were not necessary. In the second crop harvest, weed management was performed with two herbicide applications, the first at sowing and the second at 42 days after emergence (DAE) using tembotrione $\left(180 \mathrm{~mL} \mathrm{ha}^{-1}\right.$ of commercial product) + atrazine ( $5.0 \mathrm{~L} \mathrm{ha}^{-1}$ of commercial product). Pest control was performed with two sprays, the first at seeding and the second at $46 \mathrm{DAE}$ using methomyl $\left(0.4 \mathrm{~L} \mathrm{ha}^{-1}\right.$ of the active ingredient) + (imidacloprid + beta-cyfluthrin) (700 $\mathrm{mL} \mathrm{ha}^{-1}$ of commercial product). The applications of the phytosanitary products were carried out with tractor sprayer, using a spraying volume equivalent to $150 \mathrm{~L} \mathrm{ha}^{-1}$.

At the silking (R1 stage), 15 corn leaves (opposite and below the spike) per plot were sampled according to the methodology of Malavolta et al. (1997). In the laboratory, leaves were washed with deionized water, oven-dried at $65^{\circ} \mathrm{C}$ for $72 \mathrm{~h}$, and finely ground in a Willey mill. Total $\mathrm{N}$ concentration was determined by the Kjeldahl method with digestion in sulfuric acid solution and vapor distillation as described by Silva \& Queiroz (2006).

Relative chlorophyll index (RCI) was measured at the R1 stage using a portable chlorophyll meter, clorofiLOG model CFL-1030 (Falker Automação Agrícola Ltda., Porto Alegre, RS, Brazil), with five measurements per plot at the central part of the ear leaf.

In the R1 stage, nitrate reductase (NR) enzyme activity was also determined according to the method described by Majerowicz et al. (2003). Portions of the ear leaf from five corn plants were cut and used for the determination of nitrate reductase because it is the part of the plant with the highest NR activity (Reed et al., 1980). The material was collected between 10:00 and 12:00 h, period of the day when the plants received at least three hours of sunlight and the NR already reached its maximum activity (Reed et al., 1980; Lillo, 1984).

At harvest, carried out at $103 \mathrm{DAE}$ ( $1^{\text {st }}$ crop harvest) and at $146 \mathrm{DAE}$ ( $2^{\text {nd }}$ harvest), the plant height, first ear insertion height, one hundred grain mass, grain yield and grain $\mathrm{N}$ concentration were measured. The plant height and first ear insertion height were determined in 10 plants per plot, considering the distance from the soil level to the insertion of the corn tassel and the insertion of the first ear, respectively. Grain yield was determined from the harvesting of the corn ears contained in the central portion of each plot $(1.35 \times 4.00 \mathrm{~m})$. Grains were cleaned and weighed, and the grain yield was estimated after the correction of grain weights to $13 \%$ of moisture. The mass of 1,000 grains was determined by the average of three measurements of 100 grains taken at random. A sample of corn grains per plot was taken to determine the total $\mathrm{N}$ concentration. The samples were dried, ground and subjected to $\mathrm{N}$ determination, according to the methodology described by Malavolta et al. (1997).

Data were submitted to analysis of variance separately for each experiment and the means of the treatments grouped by the Scott-Knott test at the $\mathrm{p} \leq 0.05$.

\section{RESUlts AND Discussion}

The inoculation of $A$. brasilense modified the concentrations of $\mathrm{N}$ in the corn leaf tissue. The treatments that resulted in higher leaf $\mathrm{N}$ concentration in the $1^{\text {st }}$ crop harvest was with $\mathrm{N}$ fertilizer application and without inoculation (US $+\mathrm{N} 1$ and US $+\mathrm{N} 2$ ) or with the application of $A$. brasilense in the sowing furrow (IF $+\mathrm{N} 1$ and IF $+\mathrm{N} 2)$. In the $2^{\text {nd }}$ crop harvest, the treatments did not influence the leaf $\mathrm{N}$ concentration in the corn plants (Table 2).

The leaf $\mathrm{N}$ concentration is highly related to the amount of nutrient absorbed by the plants (Gazola et al., 2014). These authors reported a positive correlation between the increase of $\mathrm{N}$ doses applied with leaf $\mathrm{N}$ concentration, plant height and grain yield of the second crop harvest. The highest concentration of $\mathrm{N}$ in the corn leaves reported by these authors was $24.2 \mathrm{~g} \mathrm{~kg}^{-1}$ of $\mathrm{N}$; this concentration is close to the average obtained in the $2^{\text {nd }}$ crop harvest $\left(24.84 \mathrm{~g} \mathrm{~N} \mathrm{~kg}^{-1}\right)$ and above the value observed in the first-crop corn $\left(22.23 \mathrm{~g} \mathrm{~N} \mathrm{~kg}^{-1}\right)$.

The inoculation of $A$. brasilense in the seeds associated to the application of the lower $\mathrm{N}$ fertilizer dose (IS $+\mathrm{N} 1$ ) resulted in the higher $\mathrm{N}$ concentration in the corn grains in the $1^{\text {st }}$ crop harvest (Table 2). The highest grain $\mathrm{N}$ concentration (13.04 $\mathrm{g} \mathrm{kg}^{-1}$ ) 
Table 2. Leaf nitrogen concentration, grain nitrogen concentration and nitrate reductase activity as affected by the application methods of Azospirillum brasilense associated to the doses of nitrogen fertilizer application in the corn grown in the first (2014/2015) and in the second crop harvest (2016)

\begin{tabular}{|c|c|c|c|c|c|c|}
\hline \multirow{3}{*}{ Treatments ${ }^{1}$} & \multicolumn{2}{|c|}{ Leaf N concentration } & \multirow{2}{*}{\multicolumn{2}{|c|}{ Grain N concentration }} & \multirow{2}{*}{\multicolumn{2}{|c|}{$\begin{array}{l}\text { Nitrate reductase activity } \\
\left(\mu \mathrm{mol} \mathrm{g} \mathrm{g}^{-1} \mathrm{~h}^{-1}\right)\end{array}$}} \\
\hline & \multicolumn{2}{|c|}{$\left(\mathrm{g} \mathrm{kg}^{-1}\right)$} & & & & \\
\hline & $1^{\text {st }}$ harvest $^{2}$ & $2^{\text {nd }}$ harvest $t^{2}$ & $1^{\text {st }}$ harvest $^{2}$ & $2^{\text {nd }}$ harvest $^{2}$ & $1^{\text {st }}$ harvest $^{2}$ & $2^{\text {nd }}$ harvest ${ }^{2}$ \\
\hline US + N1 & $25.30 \mathrm{a}$ & $26.84 \mathrm{a}$ & $10.03 d$ & $12.81 \mathrm{a}$ & $2.35 b$ & $2.82 \mathrm{C}$ \\
\hline $\mathrm{US}+\mathrm{N} 2$ & $26.83 \mathrm{a}$ & $25.31 \mathrm{a}$ & $9.71 \mathrm{~d}$ & $14.87 \mathrm{a}$ & $2.39 b$ & $2.84 \mathrm{C}$ \\
\hline IS + N0 & $20.09 \mathrm{c}$ & $23.67 \mathrm{a}$ & $10.92 \mathrm{c}$ & $14.03 \mathrm{a}$ & $1.68 \mathrm{e}$ & $2.79 \mathrm{C}$ \\
\hline $\mathrm{IS}+\mathrm{N} 1$ & $22.53 b$ & $24.69 \mathrm{a}$ & $13.04 \mathrm{a}$ & $14.53 \mathrm{a}$ & $1.51 \mathrm{f}$ & $2.69 \mathrm{~d}$ \\
\hline $\mathrm{IS}+\mathrm{N} 2$ & $20.17 \mathrm{c}$ & $25.31 \mathrm{a}$ & $11.13 \mathrm{c}$ & $14.44 \mathrm{a}$ & $2.79 \mathrm{a}$ & $2.96 \mathrm{~b}$ \\
\hline $\mathrm{IF}+\mathrm{N} 0$ & $20.97 \mathrm{C}$ & $23.69 \mathrm{a}$ & $11.94 \mathrm{~b}$ & $13.31 \mathrm{a}$ & $2.22 \mathrm{C}$ & $2.04 \mathrm{e}$ \\
\hline $\mathrm{IF}+\mathrm{N} 1$ & $25.73 \mathrm{a}$ & $24.76 \mathrm{a}$ & $8.33 \mathrm{e}$ & $13.58 \mathrm{a}$ & $1.77 \mathrm{~d}$ & $3.11 \mathrm{a}$ \\
\hline $\mathrm{IF}+\mathrm{N} 2$ & $27.45 \mathrm{a}$ & $24.42 \mathrm{a}$ & $10.40 \mathrm{~d}$ & $14.13 \mathrm{a}$ & $1.68 \mathrm{e}$ & $1.65 \mathrm{f}$ \\
\hline F value & $23.50^{* \star}$ & $1.28^{\mathrm{ns}}$ & $43.20^{* *}$ & $2.39^{\text {ns }}$ & $987.60^{* \star}$ & $344.13^{\star *}$ \\
\hline CV (\%) & 1.82 & 7.48 & 3.53 & 8.97 & 1.21 & 2.01 \\
\hline
\end{tabular}

Details of treatments are given in Table 1

${ }^{2}$ Mean followed by the same letter in the columns, do not differ by the Scott-Knott test at $\mathrm{p} \leq 0.05$

in this treatment was $32.1 \%$ higher than the average of the treatments without inoculation $\left(9.87 \mathrm{~g} \mathrm{~kg}^{-1}\right)$ and $27.5 \%$ higher than the mean values obtained with the application of $A$. brasilense in the sowing furrow $\left(10.22 \mathrm{~g} \mathrm{~kg}^{-1}\right)$. In the $2^{\text {nd }}$ crop harvest, the treatments did not result in significant effect on the $\mathrm{N}$ concentration of the grains.

The results presented here reported differences in the responses to $\mathrm{N}$ accumulation in the corn grains when inoculation was performed in the sowing furrow or seeds. While the application of $A$. brasilense in the seeds increases the concentration of $\mathrm{N}$ in the foliar tissues, in the sowing furrow resulted in lowest $\mathrm{N}$ concentrations in the corn grains. The establishment or colonization of the bacterium is a point to be considered since the availability of $\mathrm{N}$ in the soil can limit its relationship with the host plant (Pereira-Defilippi et al., 2017).

In some studies, positive responses in grain yield or nitrate reductase activity (NR) with inoculation of $A$. brasilense in seeds were obtained using a higher concentration of viable cells in their treatments $\left(5 \times 10^{8}\right.$ viable cells $\left.\mathrm{mL}^{-1}\right)$ (Martins et al., 2017; Pereira-Defilippi et al., 2017). Thus, the effects of the bacteria when inoculated in the sowing furrow can be seen in the higher $\mathrm{N}$ concentration and lower NR activity in the leaves.

The NR activity was influenced by the two maize growing seasons (Table 2). In the $1^{\text {st }}$ crop harvest, the highest value was obtained in the treatment with inoculation of $A$. brasilense in the seeds associated with the highest dose of $\mathrm{N}$ fertilizer application (IS + N2). In the $2^{\text {nd }}$ crop harvest, the highest NR activity was verified when $A$. brasilense was applied to the sowing furrow associated with the application of the lowest $\mathrm{N}$ fertilizer dose (IF + N1).

About the $\mathrm{N}$ concentration in the corn grains, some studies have shown that $\mathrm{N}$ fertilization can increase the protein content of the grains (Goron et al., 2017; Martins et al., 2017). These authors also reported that $\mathrm{N}$ fertilization had more impact on the nutritional quality of the grains, while the inoculation of A. brasilense had a more pronounced effect on the increase of grain yield.

However, Duete et al. (2009) argued that the nutrient availability induces the accumulation of $\mathrm{N}$ in corn grains at certain plant growth stages, which reported in their study the greater use of $\mathrm{N}$ by the grains when applied in the V8 stage. However, there is evidence that the efficiency of $\mathrm{N}$ uptake is reduced only from the crop flowering. Thus, the influence of the bacteria on the grain $\mathrm{N}$ concentration observed in this study may be a result of later supply of $\mathrm{N}$. Another study that evidenced this fact was carried out by Silva et al. (2005), which obtained an increase in yield and protein concentration of corn grains with $\mathrm{N}$ fertilizer application after the silking (R1 stage). Thus, they suggest that hybrids more responsive to $\mathrm{N}$ fertilization retain these characteristics, maintaining the nitrogen uptake by the roots and their remobilization to the seeds.

Among the metabolic responses resulting from the action of A. brasilense, it is possible to highlight the greater development of the roots, which allows for a greater recovery of $\mathrm{N}$ applied (Martins et al., 2017). This increase in roots is due to higher hormonal activity, mainly auxins (Puente et al., 2017) and the symbiotic fixation of $\mathrm{N}_{2}$ (Brusamarello-Santos et al., 2017). It should be noted that the colonization and metabolic production capacity of the bacteria are dependent on the genotypes (Brusamarello-Santos et al., 2017), edaphoclimatic conditions (Martins et al., 2017) and soil N availability (Pereira-Defilippi et al., 2017). In other cereal crops, the gain in $\mathrm{N}$ accumulation in the grains in inoculated plants, such as wheat and barley, has been reported (Souza et al., 2014; Barzotto et al., 2018).

Ferreira et al. (1987) evaluated the inoculation of wheat seeds with A. brasilense (strain Sp7 = ATCC29.145, Sp 107st, Sp 245 and 5NR, mutants obtained from SP245) and its effect on NR activity in roots and shoots. The results showed that the NR activity was always higher in the presence of the bacteria, suggesting a bacterial nitrate reductase activity, and when this evaluation occurred in high nitrate availability in the growth medium, it was verified that the nitrate translocation to the reduction in the plant shoots decreased, but the NR activity remained high in the roots, indicating that the nutrient was translocated in its reduced and assimilable form, which led to the greater dry matter accumulation of the plants. The $\mathrm{N}$ concentration of the plant tissues was not influenced by inoculation of $A$. brasilense, but less soluble $\mathrm{N}$ was obtained in the inoculated plants, indicating its greater assimilation.

Pereira-Defilippi et al. (2017) reported that A. brasilense is capable of stimulating the transcription of genes encoding nitrate reductase enzyme in corn plants. The size of this stimulus is affected by the inoculation method, by the availability of $\mathrm{N}$, and especially by the genetic material used. 
Pereira-Defilippi et al. (2017) showed that while corn hybrids obtained distinct increases in gene expression, the varieties did not respond to inoculation.

Reis-Júnior et al. (2008) reported that the variability of the results of $A$. brasilense inoculation research had been commonly observed, mainly due to inconsistency in root colonization, inoculum survival problems or environmental conditions unfavorable to the bacterium. Thus, the treatments used affected the capacity of bacterial nitrate reductase production in different modes. The treatments with inoculation in the sowing furrow and $\mathrm{N}$ fertilization in the $1^{\text {st }}$ crop corn $(\mathrm{IF}+\mathrm{N} 1$ and $\mathrm{IF}+\mathrm{N} 2)$, followed by inoculation in the seeds in association with the lower $\mathrm{N}$ application dose (IS + N1) (Table 2) resulted in low NR activity and high $\mathrm{N}$ concentration in corn leaves, indicating a lower amount of $\mathrm{N}$ absorbed by the roots and consequently lower NR enzyme activity in the plant shoots, as proposed by Ferreira et al. (1987).

In the $2^{\text {nd }}$ crop harvest, the mean value of treatments for $\mathrm{NR}$ activity was $2.61 \mu \mathrm{mol} \mathrm{g} \mathrm{g}^{-1} \mathrm{~h}^{-1}$, while in the $1^{\text {st }}$ crop harvest it was $2.05 \mu \mathrm{mol} \mathrm{g} \mathrm{g}^{-1} \mathrm{~h}^{-1}$. Only the treatment with inoculation in the sowing furrow associated with high $\mathrm{N}$ dose (IF + N2) had lower NR activity in the leaves. The lower availability of water may have caused a lower supply of $\mathrm{N}$ applied, resulting in less activity of the enzyme in the leaves.

The relative chlorophyll index (RCI) was significantly influenced by treatments only in the $1^{\text {st }}$ crop corn (Table 3 ). The treatments with inoculation of $A$. brasilense in the sowing furrow had higher RCI when compared to treatments with inoculation in the seeds.

As previously reported, Ferreira et al. (1987) found that the presence of $A$. brasilense in the roots and consequent reduction of $\mathrm{N}$ by the bacterial nitrate reductase provided greater growth of the wheat plants, but did not alter the leaf $\mathrm{N}$ concentration. The authors verified reduction in soluble $\mathrm{N}$ in the leaves, indicating greater assimilation of this nutrient. This is interesting, since the excess of $\mathrm{N}$ in the leaves, if not metabolized, cannot be incorporated into the chlorophyll molecule, and is not detected by the chlorophyll meter (Blackmer \& Schepers, 1994).

In the $1^{\text {st }}$ crop harvest, the plant height was higher in the treatments with $A$. brasilense application or in the treatments that were only applied to the higher $\mathrm{N}$ fertilizer dose (US +
$\mathrm{N} 2$ ), except when the bacterium was applied in the sowing furrow and associated with a higher dose of $\mathrm{N}$ fertilizer (IF + N2) (Table 3). In the $2^{\text {nd }}$ crop harvest, there was no difference in plant height. This also occurred for the first ear insertion height, with difference only in the $1^{\text {st }}$ crop harvest, but the treatment with $A$. brasilense application in the sowing furrow associated with the higher $\mathrm{N}$ dose $(\mathrm{IF}+\mathrm{N} 2)$ resulted in higher ear insertion height, followed by treatment with inoculation in the seeds and higher $\mathrm{N}$ fertilizer dose (IS + N2), while the other treatments had the lowest values.

Some authors have related the higher plant height of corn to plant-bacterial interaction through the production of plant hormones (Hungria et al., 2011; Kappes et al., 2013), but also to the greater use of $\mathrm{N}$, which may influence growth of plants (Repke et al., 2013). This was verified in this study, in the first crop harvest, when the treatments without inoculation (US + $\mathrm{N} 1$ and US + N2) were compared. Even plants not fertilized with $\mathrm{N}$, but inoculated with $A$. brasilense, presented higher height, except when $A$. brasilense was applied in the sowing furrow in association with the highest $\mathrm{N}$ dose (IF + N2). In the $2^{\text {nd }}$ crop harvest, the climatic conditions may have reduced the response to $\mathrm{N}$, since there was no rainfall in approximately three weeks after the application of the $\mathrm{N}$ fertilizer in topdressing (Figure 1). According to Martins et al. (2017), climatic conditions may affect plant response to inoculation.

As reported by Sangoi et al. (2002), plant height and ear insertion height are strongly influenced by the balance of hormones in plant growth zones, especially the auxin concentration. When the plants have greater accumulation in the stem growth regions and male inflorescence, changes in the tissues that lead to greater plant height and greater ear insertion height can occur, due to the delay in the female floral differentiation about the male inflorescence. As A. brasilense is known for the production of auxins, plant morphological changes may be due to this plant-bacterial interaction.

The mass of 1,000 grains was not influenced by treatments in the $1^{\text {st }}$ crop harvest (Table 4 ). In the $2^{\text {nd }}$ crop harvest, the mass of 1,000 grains was higher with the application of the higher $\mathrm{N}$ fertilizer dose and in the absence of inoculation (US $+\mathrm{N} 2$ ) or when the A. brasilense was applied in the sowing furrow (IF + N2).

For the corn grain mass, a great variation has been observed in the studies with plants inoculated with A. brasilense or

Table 3. Relative chlorophyll index, plant height and first ear insertion height as affected by the application methods of Azospirillum brasilense associated to the doses of nitrogen fertilizer application in the corn grown in the first (2014/2015) and in the second crop harvest (2016)

\begin{tabular}{|c|c|c|c|c|c|c|}
\hline \multirow{3}{*}{ Treatments ${ }^{1}$} & \multirow{2}{*}{\multicolumn{2}{|c|}{ Relative chlorophyll index }} & \multicolumn{2}{|c|}{ Plant height } & \multicolumn{2}{|c|}{ First ear insertion height } \\
\hline & & & & & & \\
\hline & $1^{\text {st }}$ harvest $^{2}$ & $2^{\text {nd }}$ harvest $^{2}$ & $1^{\text {st }}$ harvest $^{2}$ & $2^{\text {nd }}$ harvest $^{2}$ & $1^{\text {st }}$ harvest $^{2}$ & $2^{\text {nd }}$ harvest $^{2}$ \\
\hline US + N1 & 56.48 b & $47.20 \mathrm{a}$ & $1.84 \mathrm{~b}$ & $1.70 \mathrm{a}$ & $0.60 \mathrm{c}$ & $0.57 \mathrm{a}$ \\
\hline $\mathrm{US}+\mathrm{N} 2$ & $57.10 \mathrm{~b}$ & $48.08 \mathrm{a}$ & $1.93 \mathrm{a}$ & $1.65 \mathrm{a}$ & $0.61 \mathrm{c}$ & $0.56 \mathrm{a}$ \\
\hline $\mathrm{IS}+\mathrm{NO}$ & $57.68 \mathrm{~b}$ & $48.68 \mathrm{a}$ & $1.94 \mathrm{a}$ & $1.73 \mathrm{a}$ & $0.64 \mathrm{c}$ & $0.60 \mathrm{a}$ \\
\hline $\mathrm{IS}+\mathrm{N} 1$ & $52.12 \mathrm{C}$ & $47.61 \mathrm{a}$ & $1.89 \mathrm{a}$ & $1.75 \mathrm{a}$ & $0.62 c$ & $0.59 a$ \\
\hline $\mathrm{IS}+\mathrm{N} 2$ & $52.93 \mathrm{c}$ & $49.02 \mathrm{a}$ & $1.91 \mathrm{a}$ & $1.74 \mathrm{a}$ & $0.71 \mathrm{~b}$ & $0.61 \mathrm{a}$ \\
\hline $\mathrm{IF}+\mathrm{N} 0$ & $59.61 \mathrm{a}$ & $48.83 \mathrm{a}$ & $1.94 \mathrm{a}$ & $1.65 \mathrm{a}$ & $0.61 \mathrm{c}$ & $0.56 \mathrm{a}$ \\
\hline $\mathrm{IF}+\mathrm{N} 1$ & $61.98 \mathrm{a}$ & $48.33 \mathrm{a}$ & $1.88 \mathrm{a}$ & $1.71 \mathrm{a}$ & $0.56 \mathrm{c}$ & $0.62 \mathrm{a}$ \\
\hline $\mathrm{IF}+\mathrm{N} 2$ & $61.72 \mathrm{a}$ & $47.28 \mathrm{a}$ & $1.83 \mathrm{~b}$ & $1.64 \mathrm{a}$ & $0.76 \mathrm{a}$ & $0.62 \mathrm{a}$ \\
\hline F value & $15.53^{* *}$ & $0.169^{n s}$ & $4.61^{* *}$ & $0.64^{\mathrm{ns}}$ & $13.80^{* *}$ & $0.92^{\text {ns }}$ \\
\hline CV (\%) & 2.79 & 6.48 & 1.82 & 5.41 & 4.83 & 7.58 \\
\hline
\end{tabular}

${ }^{1}$ Details of treatments are given in Table 1

${ }^{2}$ Mean followed by the same letter in the columns, do not differ by the Scott-Knott test at $\mathrm{p} \leq 0.05$ 
Table 4. Mass of 1,000 grains and grain yield as affected by the application methods of Azospirillum brasilense associated to the doses of nitrogen fertilizer application in the corn grown in the first (2014/2015) and in the second crop harvest (2016)

\begin{tabular}{|c|c|c|c|c|}
\hline \multirow{2}{*}{ Treatments $^{1}$} & \multicolumn{2}{|c|}{ Mass of 1,000 grains $(\mathrm{g})$} & \multicolumn{2}{|c|}{ Grain yield $\left(\mathrm{kg} \mathrm{ha}^{-1}\right)$} \\
\hline & $1^{\text {st }}$ harvest $^{2}$ & $2^{\text {nd }}$ harvest $^{2}$ & $1^{\text {st }}$ harvest ${ }^{2}$ & $2^{\text {nd }}$ harvest $^{2}$ \\
\hline US + N1 & $318.2 \mathrm{a}$ & $324.4 \mathrm{~b}$ & 10,331 b & $7,864 \mathrm{c}$ \\
\hline $\mathrm{US}+\mathrm{N} 2$ & $322.3 \mathrm{a}$ & $345.3 \mathrm{a}$ & 11,159 a & $9,708 \mathrm{a}$ \\
\hline IS + N0 & $307.5 \mathrm{a}$ & $325.1 \mathrm{~b}$ & 10,694 b & $8,621 \mathrm{~b}$ \\
\hline $\mathrm{IS}+\mathrm{N} 1$ & $315.4 \mathrm{a}$ & $324.1 \mathrm{~b}$ & $10,398 b$ & $8,678 \mathrm{~b}$ \\
\hline $\mathrm{IS}+\mathrm{N} 2$ & $341.4 \mathrm{a}$ & $331.2 \mathrm{~b}$ & $10,500 b$ & $8,867 \mathrm{~b}$ \\
\hline $\mathrm{IF}+\mathrm{NO}$ & $313.3 \mathrm{a}$ & $318.2 \mathrm{~b}$ & $10,414 b$ & $8,714 b$ \\
\hline $\mathrm{IF}+\mathrm{N} 1$ & $327.3 \mathrm{a}$ & $329.5 \mathrm{~b}$ & 10,984 a & $7,757 \mathrm{c}$ \\
\hline $\mathrm{IF}+\mathrm{N} 2$ & $320.7 \mathrm{a}$ & $345.9 \mathrm{a}$ & $11,039 \mathrm{a}$ & $9,013 \mathrm{~b}$ \\
\hline F value & $3.47^{*}$ & $2.51^{*}$ & $2.70^{*}$ & $17.47^{\star \star}$ \\
\hline CV (\%) & 1.79 & 3.34 & 3.24 & 3.32 \\
\hline
\end{tabular}

${ }^{1}$ Details of treatments are given in Table 1

${ }^{2}$ Mean followed by the same letter in the columns, do not differ by the Scott-Knott test at $\mathrm{p} \leq 0.05$

fertilized with $\mathrm{N}$. Some results show that $\mathrm{N}$ availability may potentiate mass gain in grains, and consequently increase in grain weight with the application of high doses of $\mathrm{N}$ fertilizer (Repke et al., 2013). Other studies reported variations only among genetic materials (Cadore et al., 2016), while Kappes et al. (2017) did not respond with the inoculation or application of $\mathrm{N}$ doses. These authors, however, have argued that the adequate $\mathrm{N}$ availability in the period between flowering and the beginning of the grain filling is fundamental so that its translocation to the grains is effective, without losses in the specific mass.

Portugal et al. (2017) obtained a lower mass of 1,000 grains when the seeds were inoculated with $A$. brasilense, similar to the result obtained for the majority of treatments inoculated in the present study. The authors' explanation for this negative effect is that the bacterium, being heterotrophic, requires $\mathrm{N}$ for its survival, being able to compete with the plant in case of low nutrient availability in the soil. Due to the lower availability of water after the application of $\mathrm{N}$ fertilizer in the $2^{\text {nd }}$ crop harvest (Figure 1), it is possible that its absorption has been reduced, resulting in a lower translocation in seed formation.

The highest grain yield in the first corn crop harvest was obtained with the application of the highest $\mathrm{N}$ fertilizer dose and in the absence of inoculation (US + N2) or when the inoculation was performed in the sowing furrow (IF + N2) and also in the lowest $\mathrm{N}$ dose with $A$. brasilense applied in the sowing furrow $(\mathrm{IF}+\mathrm{N} 1)$, that is, it was possible to reduce the $\mathrm{N}$ fertilizer dose obtaining the same corn grain yield. The other treatments did not differ from each other. In the $2^{\text {nd }}$ crop harvest, the highest grain yield was obtained only with the highest $\mathrm{N}$ fertilizer dose and without inoculation (US + $\mathrm{N} 2$ ), while the lower $\mathrm{N}$ dose without inoculation (US + N1) or when the inoculation was performed in the sowing furrow $(\mathrm{IF}+\mathrm{N} 1)$ resulted in lower grain yield.

The importance of $\mathrm{N}$ to obtain high productivity in corn crop is indisputable. It should be emphasized the interference of $A$. brasilense in the $\mathrm{N}$ metabolism for the plant, with a higher recovery of $\mathrm{N}$ applied (Martins et al., 2017) or its biological fixation (Brusamarello-Santos et al., 2017), as well as the activity of bacterial nitrate reductase (Ferreira et al., 1987), which resulted in high leaf $\mathrm{N}$ concentration and higher relative chlorophyll index.
This can be seen in the $1^{\text {st }}$ crop harvest when the inoculation of $A$. brasilense in the sowing furrow with the application of the lower $\mathrm{N}$ dose resulted in grain yield similar to the treatment that was fertilized only with the higher $\mathrm{N}$ fertilizer dose, or in treatments inoculated with A. brasilense which were not fertilized with $\mathrm{N}$, but obtained grain yield similar to the others that were fertilized with $\mathrm{N}$. In the $2^{\text {nd }}$ crop harvest, this effect can also be highlighted, since the treatments inoculated with $A$. brasilense that were not fertilized with $\mathrm{N}$ obtained grain yield superior to the non-inoculated treatment and fertilized with the lower $\mathrm{N}$ dose, although the highest grain yield was obtained only with the application of the higher $\mathrm{N}$ fertilizer dose.

\section{Conclusions}

1. In the first crop harvest, the use of $500 \mathrm{~mL}$ of the inoculant containing $A$. brasilense in the sowing furrow in association with application of 10 or $20 \mathrm{~kg} \mathrm{~N} \mathrm{ha}^{-1}$ at sowing and 50 or $100 \mathrm{~kg} \mathrm{~N} \mathrm{ha}^{-1}$ at topdressing provided higher $\mathrm{N}$ concentration and relative chlorophyll index in the corn leaves, while the application of $100 \mathrm{~mL}$ of the inoculant per $20 \mathrm{~kg}$ of seeds in association with the use of $10 \mathrm{~kg} \mathrm{~N} \mathrm{ha}^{-1}$ at sowing and $50 \mathrm{~kg} \mathrm{~N} \mathrm{ha}^{-1}$ at topdressing provided a higher $\mathrm{N}$ concentration in the corn grains.

2. Nitrate reductase activity in the corn leaves was lower when inoculation of $A$. brasilense was carried out in the seeds.

3. In the first crop harvest, inoculation of $A$. brasilense provided higher plant height, and did not increase grain yield of corn crop; however, with inoculation in the sowing furrow, it was possible to reduce the amount of $\mathrm{N}$ fertilizer applied by $50 \%$ without causing loss of grain yield.

4. In the second crop harvest, the inoculation did not promote effects on the $\mathrm{N}$ concentration in the leaves and in the grains and did not modify the chlorophyll index and height of the corn plants. The inoculation at the sowing furrow associated with the application of the higher $\mathrm{N}$ fertilizer dose resulted in lower nitrate reductase activity in the leaves.

5. In the second crop harvest, a greater mass of 1,000 grains was obtained with the application of the higher $\mathrm{N}$ fertilizer dose alone or in combination with inoculation in the sowing furrow. The highest grain yield was obtained only with the application of the highest $\mathrm{N}$ fertilizer dose.

\section{Literature Cited}

Barzotto, G. R.; Lima, S. F.; Santos, O. F.; Piati, G. L.; Wassolowski, C. R. Adubação nitrogenada e inoculação com Azospirillum brasilense em cevada. Nativa, v.6, p.1-8, 2018. https://doi.org/10.31413/ nativa.v6i1.4611

Blackmer, T. M.; Schepers, J. S. Techniques for monitoring crop nitrogen status in corn. Communications in Soil Science and Plant Analysis, v.25, p.1791-1800, 1994. https://doi. org/10.1080/00103629409369153

Brusamarello-Santos, L. C.; Gilard, F.; Brulé, L.; Quilleré, I.; Gourion, B.; Ratet, P.; Souza, E. M. de; Lea, P. J.; Hirel, B. Metabolic profiling of two maize (Zea mays L.) inbred lines inoculated with the nitrogen fixing plant-interacting bacteria Herbaspirillum seropedicae and Azospirillum brasilense. Plos One, v.12, p.1-19, 2017. https://doi.org/10.1371/journal.pone.0174576 
Cadore, R.; Costa Netto, A. P. da; Reis, E. F. dos; Ragagnin, V. A.; Freitas, D. S.; Lima, T. P. de; Rossato, M.; D’Abadia, A. C. A. Híbridos de milho inoculados com Azospirillum brasilense sob diferentes doses de nitrogênio. Revista Brasileira de Milho e Sorgo, v.15, p.398-409, 2016. https://doi.org/10.18512/1980-6477/rbms. v15n3p398-409

Duete, R. R. C.; Muraoka, T.; Silva, E. C. da; Ambrosano, E. J.; Trivelin, P. C. O. Acúmulo de nitrogênio $\left({ }^{15} \mathrm{~N}\right)$ pelos grãos de milho em função da fonte nitrogenada em Latossolo Vermelho. Bragantia, v.68, p.463-472, 2009. https://doi.org/10.1590/S000687052009000200021

Ferreira, M. C. B.; Fernandes, M. S.; Döbereiner, J. Role of Azospirillum brasilense nitrate reductase in nitrate assimilation by wheat plants. Biology and Fertility of Soils, v.4, p.47-53, 1987.

França, S.; Mielniczuk, J.; Rosa, L. M. G.; Bergamaschi, H.; Bergonci, J. I. Nitrogênio disponível ao milho: Crescimento, absorção e rendimento de grãos. Revista Brasileira de Engenharia Agrícola e Ambiental, v.15, p.1143-1151, 2011. https://doi.org/10.1590/ S1415-43662011001100006

Gazola, D.; Zucareli, C.; Silva, R. R.; Fonseca, I. C. de B. Aplicação foliar de aminoácidos e adubação nitrogenada de cobertura na cultura do milho safrinha. Revista Brasileira de Engenharia Agrícola e Ambiental, v.18, p.700-707, 2014. https://doi. org/10.1590/S1415-43662014000700005

Goron, T. L.; Nederend, J.; Stewart, G.; Deen, B.; Raizada, M. N. Midseason leaf glutamine predicts end-season maize grain yield and nitrogen content in response to nitrogen fertilization under field conditions. Agronomy, v.7, p.1-16, 2017. https://doi.org/10.3390/ agronomy7020041

Hungria, M. Inoculação com Azospirillum brasilense: Inovação em rendimento a baixo custo. Londrina: Embrapa Soja, 2011. 36p.

Kappes, C.; Arf, O.; Arf, M. V.; Ferreira, J. P.; Bem, E. A. D.; Portugal, J. R.; Vilela, R. G. Inoculação de sementes com bactéria diazotrófica e aplicação de nitrogênio em cobertura e foliar em milho. Semina: Ciências Agrárias, v.34, p.527-538, 2013. https://doi. org/10.5433/1679-0359.2013v34n2p527

Kappes, C.; Silva, R. G. da; Ferreira, V. E. N. Aplicação foliar de Azospirillum brasilense e doses de nitrogênio em cobertura no milho safrinha. Scientia Agraria Paranaensis, v.16, p.366-373, 2017.

Lillo, C. Diurnal variation of nitrite reductase, glutamine synthetase, glutamate synthase, alanine aminotransferase and aspartate aminotransferase in barley leaves. Physiologia Plantarum, v.61, p.214-218, 1984. https://doi.org/10.1111/j.1399-3054.1984. tb05899.x

Majerowicz, N.; França, M. G. C.; Peres, L. E. P.; Médici, L. O.; Figueiredo, S. A. Fisiologia vegetal: Curso prático. Rio de Janeiro: Âmbito Cultural Edições Ltda, 2003. 138p.

Malavolta, E.; Vitti, G. C.; Oliveira, S. A. de. Avaliação do estado nutricional das plantas: Princípios e aplicações. 2.ed. Piracicaba: POTAFOS, 1997. 319p.

Martins, M. dos R.; Jantalia, C. P.; Reis, V. M.; Döwich, I.; Polidoro, J. C.; Alves, B. J. R.; Boddey, R. M.; Urquiaga, S. Impact of plant growth-promoting bactéria on grain yield protein content, and urea $^{-15} \mathrm{~N}$ recovery by maize in a Cerrado Oxisol. Plant and Soil, v.422, p.239-250, 2017. https://doi.org/10.1007/s11104-017-3193-1
Pereira-Defilippi, L.; Pereira, E. M.; Silva, F. M.; Moro, G. V. Expressed sequence tags related to nitrogen metabolismo in maize inoculated with Azospirillum brasilense. Genetics and Molecular Research, v.16, p.1-14, 2017. https://doi.org/10.4238/gmr16029682

Portugal, J. R.; Arf, O.; Peres, A. R.; Gitti, D. de C.; Garcia, N. F. S. Coberturas vegetais, doses de nitrogênio e inoculação com Azospirillum brasilense em milho no Cerrado. Revista Ciência Agronômica, v.48, p.639-649, 2017. https://doi.org/10.5935/18066690.20170074

Puente, M. L.; Gualpa, J. L.; Lopez, G. A.; Molina, R. M.; Carletti, S. M.; Cassán, F. D. The benefits of foliar inoculation with Azospirillum brasilense in soybean are explained by an auxin signaling model. Symbiosis, p.1-9, 2017. https://doi.org/10.1007/ s13199-017-0536-x

Reed, A. J.; Below, F. E.; Hageman, R. H. Grain protein accumulation and the relationship between leaf nitrate reductase and proteases activities during grain development in maize (Zea mays L.). Plant Physiology, v.66, p.1179-1183, 1980. https://doi.org/10.1104/ pp.66.1.164

Reis Júnior, F. B.; Machado, C. T. T.; Machado, A. T.; Mendes, I. C.; Mehta, A. Isolamento, caracterização e seleção de estirpes de Azospirillum amzonense e Herbaspirillum seropedicae associadas a diferentes variedades de milho cultivadas no Cerrado. Planaltina: Embrapa Cerrados, 2008. 36p.

Repke, R. A.; Cruz, S. J. S.; Silva, C. J. da; Figueiredo, P. G.; Bicudo, S. J. Eficiência da Azospirillum brasilense combinada com doses de nitrogênio no desenvolvimento de plantas de milho. Revista Brasileira de Milho e Sorgo, v.12, p.214-226, 2013. https://doi. org/10.18512/1980-6477/rbms.v12n3p214-226

Sangoi, L.; Almeida, M. L. de; Silva, P. R. F. da; Argenta, G. Bases morfofisiológicas para maior tolerância dos híbridos modernos de milho a altas densidades de plantas. Bragantia, v.61, p.101-110, 2002. https://doi.org/10.1590/S0006-87052002000200003

Silva, D. J.; Queiroz, A. C. Análise de alimentos: Métodos químicos e biológicos. 3.ed. Viçosa: UFV, 2006. 235p.

Silva, P. R. F. da; Strieder, M. L.; Coser, R. P. da S.; Rambo, L.; Sangoi, L.; Argenta, G.; Forsthofer, E. L.; Silva, A. A. da. Grain yield and kernel crude protein content increases of maize hybrids with late nitrogen side-dressing. Scientia Agricola, v.62, p.487-492, 2005. https://doi.org/10.1590/S0103-90162005000500014

Sousa, D. M. G.; Lobato, E. Calagem e adubação para culturas anuais e semiperenes. In.: Sousa, D. M. G. de; Lobato, E. (eds.). Cerrado: Correção do solo e adubação. 2.ed. Brasília: Embrapa Informação Tecnológica, 2004. p.283-315.

Souza, T. M.; Prando, A. M.; Takabayashi, C. R.; Santos, J. S. dos; Ishikawa, A. T.; Felício, A. L. de S. M.; Itano, E. N.; Kawamura, O.; Zucareli, C.; Hirooka, E. Y. Composição química e desoxinivalenol em trigo da região centro-sul do Paraná: Adubação nitrogenada em cobertura associada com Azospirillum brasilense. Semina: Ciências Agrárias, v.35, p.327-342, 2014. https://doi.org/10.5433/1679$0359.2014 \mathrm{v} 35 \mathrm{n} 1 \mathrm{p} 327$

Vale, J. C. do; Fritsche-Neto, R.; Bermudez, F.; Miranda, G. V. Efeitos gênicos de caracteres associados à eficiência no uso de nitrogênio em milho. Pesquisa Agropecuária Brasileira, v.47, p.385-392, 2012. https://doi.org/10.1590/S0100-204X2012000300010 